\title{
Production of Iron Nuggets from the Akpafu-Todzi Iron Ore and Artisanal Ferrous Slag using Post Consumer Thermosets (Waste Electrical Sockets) as Reductants*
}

\author{
${ }^{1,2}$ J. R. Dankwah, ${ }^{2}$ E. O. Baah, ${ }^{2}$ J. B. Dankwah, ${ }^{2}$ J. Dankwah, ${ }^{3}$ B. S. Agbenuvor, ${ }^{4}$ B. Amankwaa-Kyeremeh and \\ ${ }^{5} \mathrm{P}$. Koshy \\ ${ }^{1}$ University of Mines and Technology, Tarkwa, Ghana \\ ${ }^{2}$ Africa Centre of Sustainable Materials Research and Technology, Tarkwa \\ ${ }^{3}$ University of Queensland, Brisbane, Australia \\ ${ }^{4}$ University of South Australia, Adelaide, Australia \\ ${ }^{5}$ University of New South Wales, Sydney, Australia
}

Dankwah, J. R., Baah, E. O., Dankwah, J. B., Dankwah, J., Agbenuvor, B. S., Amankwaa-Kyeremeh, B. and Koshy, P. (2019), "Production of Iron Nuggets from the Akpafu-Todzi Iron Ore and Artisanal Ferrous Slag using Post Consumer Thermosets (Waste Electrical Sockets) as Reductants", Ghana Mining Journal, Vol. 19, No. 2, pp. 41-49.

\begin{abstract}
Post-consumer thermosets are difficult to recycle because, unlike thermoplastics, they cannot be remoulded to create other items as a result of the extensive cross-linkages in their structure. The increased production of thermoset blends and composites in recent years has greatly increased the amount of waste materials. However, higher levels of carbon and hydrogen present in thermosets make them a potential reductant in the iron extractive industries. In this research work, postconsumer thermoset was transformed into carbon resource through a charring process. The resulting carbonaceous material from the thermoset was used as reductant in the production of metallic iron from the Akpafu-Todzi iron ore and artisanal slag using the microwave technology through the composite pellet approach at varying firing times. Analyses by XRF, XRD and SEM/EDS showed that the Akpafu Todzi iron ore is comprised of the iron oxides hematite $\left(\mathrm{Fe}_{2} \mathrm{O}_{3}\right)$ and wustite $\left(\mathrm{Fe}_{0.942} \mathrm{O}\right)$, while the artisanal slag was predominantly fayalite $\left(\mathrm{Fe}_{2} \mathrm{SiO}_{4}\right)$. Complete reduction of the ore was attained after 120 min reduction but the maximum extent of reduction was $78.84 \%$ for the slag, demonstrating the potential of postconsumer thermosets to function effectively as a reductant in the iron extractive industry.
\end{abstract}

Keywords: Reduction; Akpafu-Todzi Iron Ore; Post Consumer Thermosets; Waste Electrical Sockets

\section{Introduction}

Waste electrical sockets (WES) are difficult to recycle because various forms are produced from thermosetting polymers which cannot be remoulded after setting. Currently, incineration at landfills remains the major mode for recycling WES. However, uncontrolled incineration of WES in the open could be a harmful process because electrical sockets are produced from melamine or urea formaldehyde, making products of such incineration processes potential hazardous materials. Work done by Dankwah et al., (2016a) has shown that controlled charring can result in the production of charred carbonaceous matter that can serve as potential reductants for iron oxide reduction.

Some research investigations have been conducted on utilisation of postconsumer plastics as reductants or as a source of energy in the metallurgical field (Matsuda et al., 2006; Nishioka et al., 2007; Matsuda et al., 2008; Ueki et al., 2008; Dankwah et al., 2011; Kongkarat et al., 2011; Murakami et al., 2009; Murakami and Kasai, 2011; Dankwah et al., 2012; Dankwah et al., 2013; Dankwah and Koshy, 2014; Dankwah et al., 2015a; Dankwah et al., 2015b). A review of these investigations shows that thermoplastic polymers and or their blends with metallurgical coke, graphite, or biomass are the dominant reductants often used for the production of metallic iron from reagent grade iron oxides or electric arc furnace (EAF) slags containing iron oxide (Dankwah et al., 2016). In addition to the above polymers and their blends, other researchers have utilised elastomers and thermosetting plastics as reductants (Dankwah et al., 2012, Mansuri et al., 2013, Rajarao et al., 2014a, Rajarao et al., 2014b, Nath et al., 2012, Dhunna et al., 2014 and Dankwah and Baawuah, 2015). This category of polymers includes end-of-life rubber tyres, compact discs, melamine and bakelite as reductants or for carbon dissolution studies. Rajarao et al. (2014b) studied the structural changes in the chars produced during the rapid pyrolysis of waste compact discs (CDs) in the temperature range $550-1550{ }^{\circ} \mathrm{C}$. They observed an increase in the porosity and $\mathrm{C} / \mathrm{O}$ ratios of the chars with an increase in the pyrolysis temperature up to $850{ }^{\circ} \mathrm{C}$. They achieved a maximum porosity at $850^{\circ} \mathrm{C}$ with char surface area of $334 \mathrm{~m}^{2} / \mathrm{g}$. Using the chars produced at $1550{ }^{\circ} \mathrm{C}$ as reductants they were able to achieve about $90 \%$ iron oxide reduction (Dankwah et al., 2016).

Recovery of iron from waste bearing ferrous slags is more complicated than from the naturally occurring 
oxide because the slag typically exists as a spinel fayalite, which is difficult to reduce carbothermally. Cheng et al. (2013) investigated the direct reduction experiment on iron-bearing waste slag. They observed that addition of $\mathrm{Al}_{2} \mathrm{O}_{3}$ to the slag can improve the metallisation rate from between 74$77 \%$ to over $88 \%$ at temperatures around $1250{ }^{\circ} \mathrm{C}$. Heo et al. (2016) investigated the recovery of iron and removal of hazardous elements from waste copper slag via a novel aluminothermic smelting reduction (ASR) process. They observed that iron recovery exhibited a maximum value at $\mathrm{Al} / \mathrm{FeO}$ ratio of 0.53. Sarfo et al. (2017) investigated the carbothermal reduction of copper smelter slag for recycling into pig iron and glass. They observed that most of the copper and iron can be recovered as pig iron from the initial slag using minor amounts of lime and alumina and treating at $1350{ }^{\circ} \mathrm{C}$ or higher for 30-90 min.

Dankwah et al. (2016a) were able to produce premium grade metallic iron nuggets from the Agbaja iron ore (Nigeria) using charred carbonaceous materials obtained from WES. More information is needed in the literature on the use of end-of-life thermosets as reductants for the production of metallic iron from other naturally occurring iron ores.

The Akpafu-Todzi iron deposit is located in the Volta Region of Ghana and is believed to be a low to medium grade ore. Processing of the ore has been on a limited scale by the local blacksmiths for simple implements like hoes and cutlasses owing to the location and grade of the ore as well as a lack of appropriate source of carbonaceous materials for effective reduction. For reduction studies, Dankwah et al. (2016b) produced metallic iron from the Akpafu-Todzi ore using carbonaceous materials generated from palm kernel shells and their blends with post-consumer high density polyethylene. However, the nature of the artisanal slag generated, as waste material as well as its processing to create valuable materials has not been widely researched into.

This work therefore investigates the potential for utilising WES as reductant for the production of metallic iron from the Akpafu-Todzi iron ore and samples of slag materials through the microwave approach. These slag samples were part of the waste obtained from the reduction of the ore by the local artisans.

\section{Resources and Methods Used}

\subsection{Carbonaceous Materials Preparation}

Samples of WES (Fig. 1) were collected from the surroundings of the University of Mines and
Technology (UMaT), Tarkwa. These were broken down into pieces and washed thoroughly to remove dust. The cleaned thermosets were thereafter air dried for two days. This was followed by charring under controlled temperature conditions for $45 \mathrm{mins}$ using a gas fired furnace.

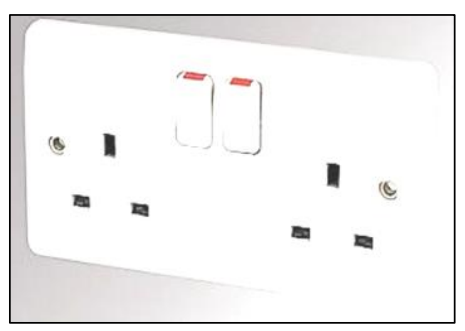

Fig. 1 Waste Electrical Socket

The charred thermoset (Fig. 2) was ground using a ball mill for 10 minutes. The ground thermoset (Fig. 3) was screened for 15 minutes at amplitude of 20 using standard sieve sizes of $106 \mu \mathrm{m}, 90 \mu \mathrm{m}, 75 \mu \mathrm{m}$

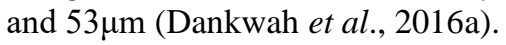

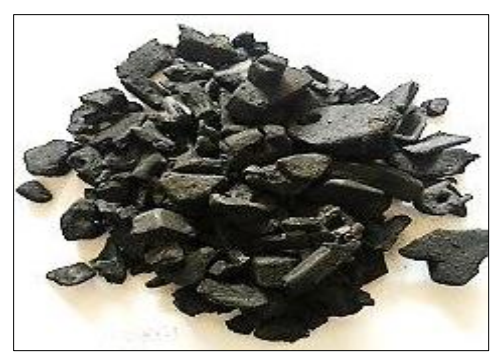

Fig. 2 Charred Electrical Socket

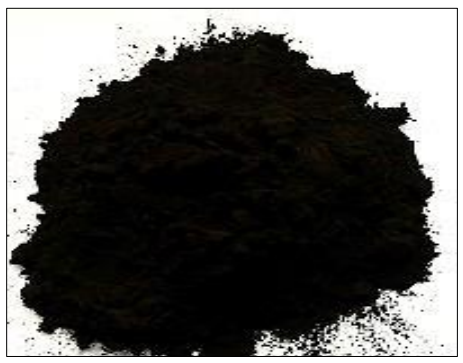

Fig. 3 Samples of Pulverised Charred Electrical Socket

\subsection{Preparation of Ore Samples}

Medium grade Akpafu-Todzi iron ore (65.947 wt \% $\mathrm{Fe}_{2} \mathrm{O}_{3}$ ) and artisanal slag samples (70.377) were used as the source of iron oxide (Table 1). The morphologies of the Akpafu-Todzi iron ore (Fig. 4) and the slag (Fig. 5) were observed by Scanning Electron Microscopy (SEM). The pulverised samples were characterised by XRD using an EMPYREAN Diffractometer. 
Table 1 Chemical Composition (XRF) of AkpafuTodzi Iron Ore and Artisanal Slag

\begin{tabular}{|l|c|c|}
\hline \multirow{2}{*}{ Component } & \multicolumn{2}{|c|}{ Composition (wt \%) } \\
\cline { 2 - 3 } & Ore & Slag \\
\hline $\mathrm{Fe}_{2} \mathrm{O}_{3}$ & 65.947 & 70.377 \\
\hline $\mathrm{SiO}_{2}$ & 20.055 & 28.412 \\
\hline $\mathrm{Al}_{2} \mathrm{O}_{3}$ & 2.340 & 2.251 \\
\hline $\mathrm{CaO}$ & 0.043 & 1.795 \\
\hline $\mathrm{Mn}_{3} \mathrm{O}_{4}$ & 0.043 & 1.433 \\
\hline $\mathrm{TiO}_{2}$ & 0.087 & 0.112 \\
\hline $\mathrm{Cr}_{2} \mathrm{O}_{3}$ & 1.218 & 0.344 \\
\hline $\mathrm{MgO}^{2}$ & 0.154 & 0.505 \\
\hline $\mathrm{P}_{2} \mathrm{O}_{5}$ & 0.296 & 0.168 \\
\hline $\mathrm{SO}_{3}$ & 0.159 & 0.046 \\
\hline $\mathrm{LOI}$ & 11.18 & 5.02 \\
\hline
\end{tabular}
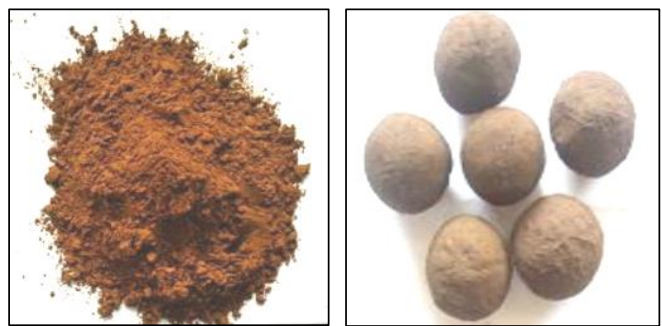

Fig. 4 Spherical Pellets formed from Milled Ore Sample and WES
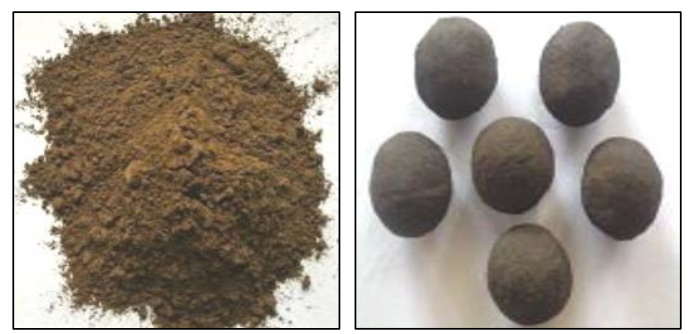

Fig. 5 Spherical Pellets formed from Milled Slag Sample and WES

\subsubsection{Reduction Studies}

Each dry pellet was placed in a fireclay crucible and positioned at the central location of the microwave as shown in (Fig. 6) to ensure maximum concentration of the radiation emitted. The crucible was taken out after the desired time of firing and quenched in air to stop any further reactions. The weight of reduced iron pellet was recorded. This procedure was repeated for the rest of the pellets at different firing times.

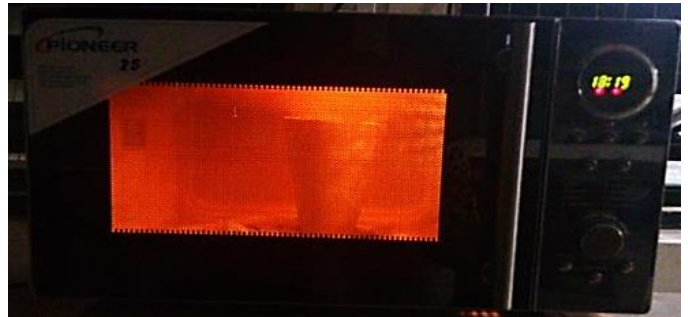

Fig. 6 Reduction Process in a Domestic Microwave Oven

\section{Results and Discussion}

\subsection{Nature of Charred Carbonaceous Material Derived from WES}

Figs. 7 and 8 show SEM/EDS analyses of the solid product obtained after charring WES. Elemental analyses of regions 1 and 2 show a carbon content (of $67.35 \mathrm{wt} \%$ and 64.13 ) reasonably above those of various forms of coals $(\sim 60 \mathrm{wt} \%)$ and polyethylene terephthalate (PET) $(\sim 62.5 \mathrm{wt} \%)$. It should therefore be possible to reduce iron oxide with charred WES. However, the efficiency of reduction will depend on the nature of ash obtained after the charring process.

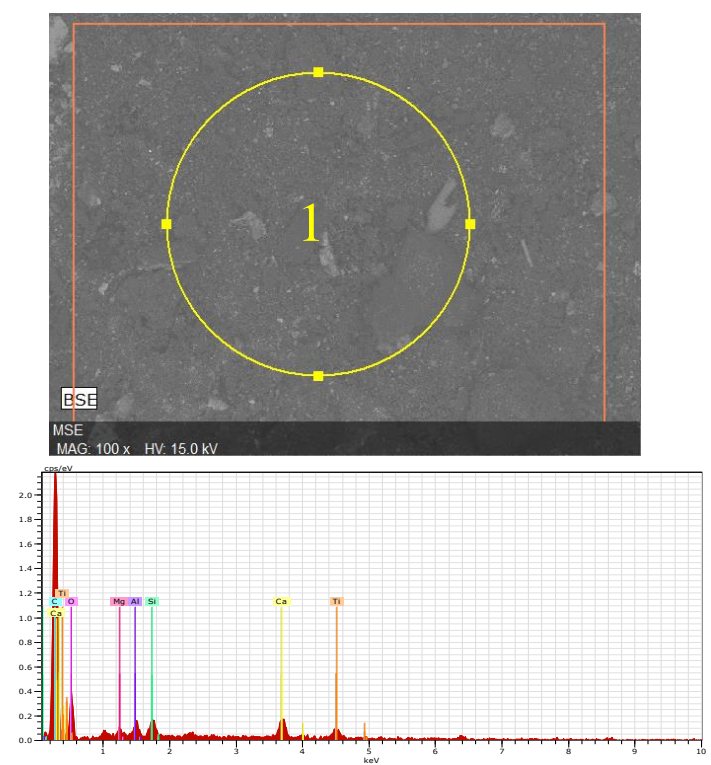

\begin{tabular}{|l|c|c|}
\hline $\begin{array}{c}\text { Element (K- } \\
\text { series) }\end{array}$ & Weight \% & Atomic \% \\
\hline $\mathrm{C}$ & 67.35 & 76.11 \\
\hline $\mathrm{O}$ & 24.56 & 20.84 \\
\hline $\mathrm{Ca}$ & 3.26 & 1.11 \\
\hline $\mathrm{Ti}$ & 2.17 & 0.62 \\
\hline $\mathrm{Si}$ & 1.31 & 0.63 \\
\hline $\mathrm{Al}$ & 0.90 & 0.45 \\
\hline $\mathrm{Mg}$ & 0.44 & 0.24 \\
\hline $\mathrm{SUM}$ & 100 & 100 \\
\hline
\end{tabular}

Fig 7 SEM/EDX Analysis of Region 1 from Charred WES 

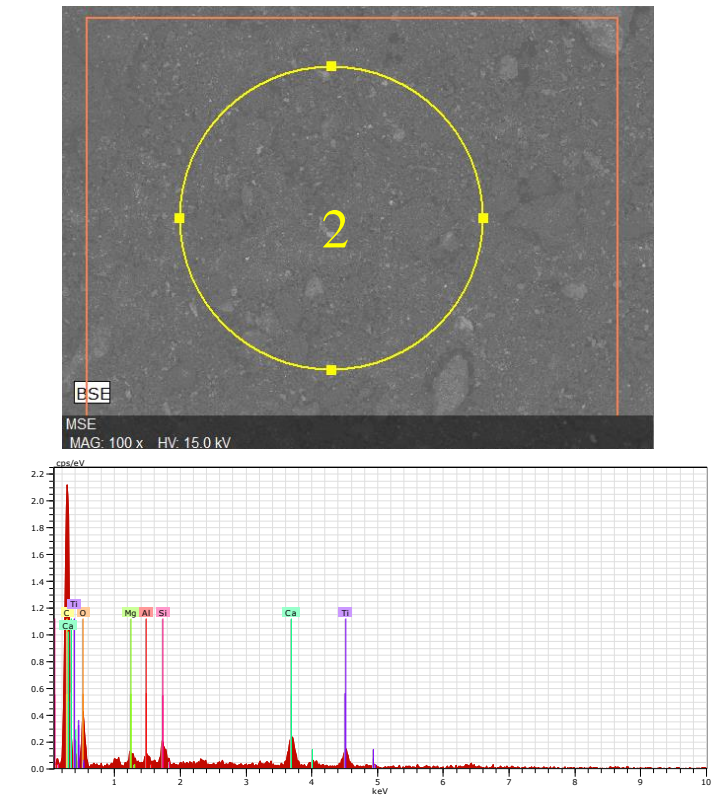

\begin{tabular}{|l|c|c|}
\hline \multicolumn{1}{|c|}{$\begin{array}{c}\text { Element (K- } \\
\text { series) }\end{array}$} & Weight \% & Atomic \% \\
\hline $\mathrm{C}$ & 64.13 & 74.06 \\
\hline $\mathrm{O}$ & 25.01 & 21.69 \\
\hline $\mathrm{Ca}$ & 4.18 & 1.45 \\
\hline $\mathrm{Ti}$ & 2.95 & 0.86 \\
\hline $\mathrm{Si}$ & 1.80 & 0.89 \\
\hline $\mathrm{Mg}$ & 1.19 & 0.68 \\
\hline $\mathrm{Al}$ & 0.74 & 0.38 \\
\hline $\mathrm{SUM}$ & 100 & 100 \\
\hline
\end{tabular}

Fig. 8 SEM/EDX Analysis of Region 2 from

\section{Charred WES}

The morphology of the ash obtained after the charring process is shown in the SEM of Fig 9 whilst the XRD is shown in Fig 10. The ash particles appear to be irregularly shaped as indicated in Fig 6 and consist of several crystalline peaks of calcite, quartz, corundum, halite, silicon and bornite.

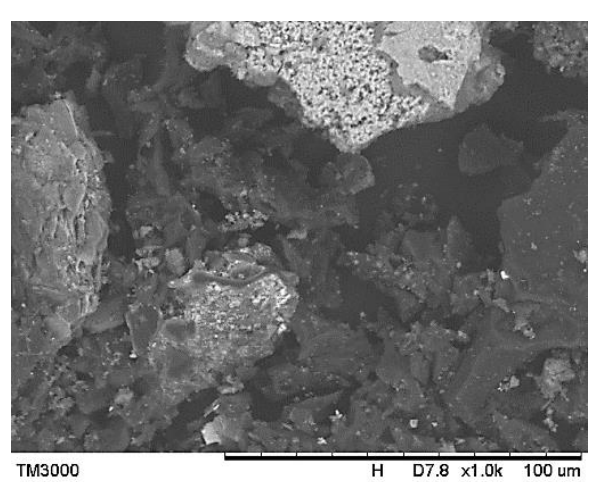

Fig. 9 SEM Photomicrograph of Ash obtained after Charring of WES (Dankwah et al., 2016a)

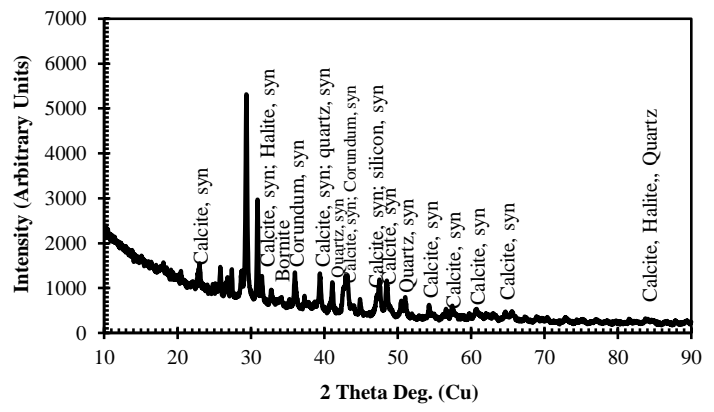

Fig. 10 XRD Patterns of Ash obtained after the Charring Process (Dankwah et al., 2016a)

\subsection{The Nature of the Akpafu-Todzi Iron Ore}

The SEM/EDS analyses of the Akpafu-Todzi iron ore before reduction are illustrated in Figs 11 and 12 for two regions 1 and 2. Region 1 shows an iron content of 44.07 wt \%, with Region 2 slightly different at 42.88 wt $\%$.

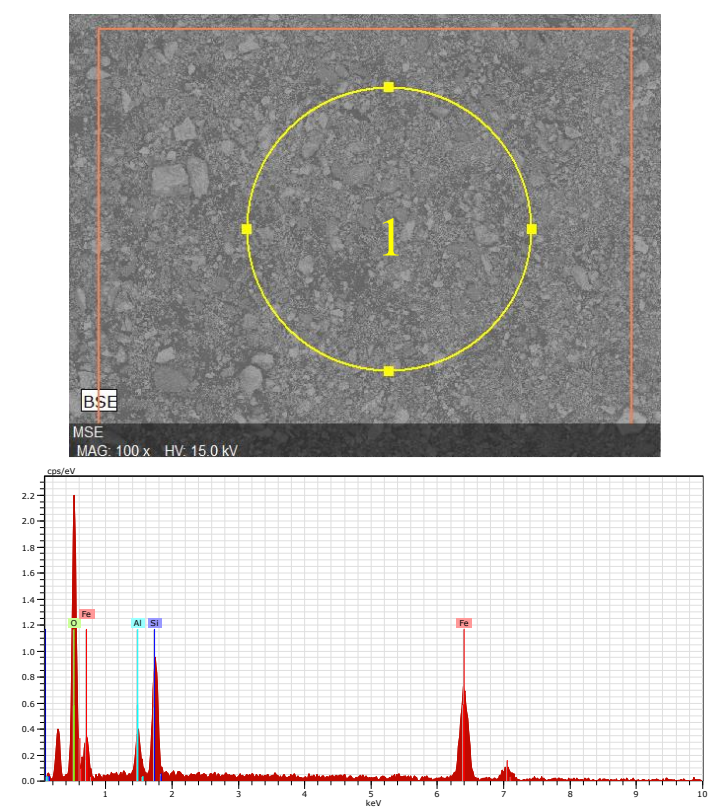

\begin{tabular}{|l|c|c|}
\hline \multicolumn{1}{|c|}{$\begin{array}{c}\text { Element (K- } \\
\text { series) }\end{array}$} & Weight \% & Atomic \% \\
\hline $\mathrm{Fe}$ & 44.07 & 20.45 \\
\hline $\mathrm{O}$ & 39.83 & 64.52 \\
\hline $\mathrm{Si}$ & 11.93 & 11.01 \\
\hline $\mathrm{Al}$ & 4.18 & 4.01 \\
\hline $\mathrm{SUM}$ & 100 & 100 \\
\hline
\end{tabular}

Fig. 11 SEM/EDS Analysis of Akpafu-Todzi Iron Ore (Region 1) (Dankwah et al., 2016b) 


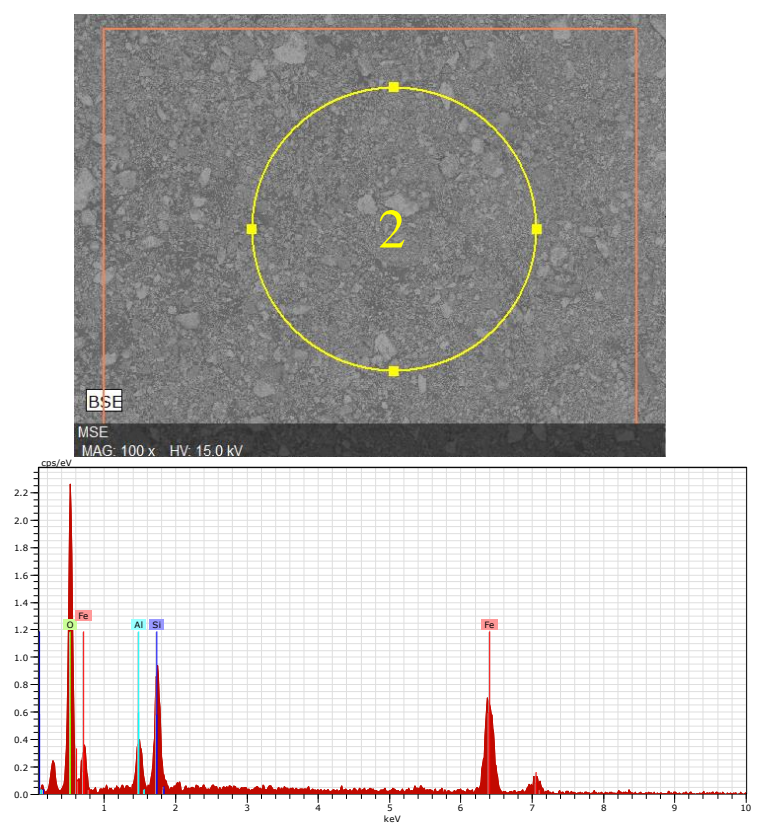

\begin{tabular}{|l|c|c|}
\hline \multicolumn{1}{|c|}{$\begin{array}{c}\text { Element (K- } \\
\text { series) }\end{array}$} & Weight \% & Atomic \% \\
\hline $\mathrm{Fe}$ & 42.88 & 19.78 \\
\hline $\mathrm{O}$ & 39.88 & 64.22 \\
\hline $\mathrm{Si}$ & 12.25 & 11.24 \\
\hline $\mathrm{Al}$ & 4.98 & 4.76 \\
\hline $\mathrm{SUM}$ & 100 & 100 \\
\hline
\end{tabular}

Fig. 12 SEM/EDS Analysis of Akpafu-Todzi Iron Ore (Region 2) (Dankwah et al., 2016b)

The ore was also characterised by XRD. The diffraction patterns are shown in Fig 13. The diffraction patterns correspond to those of $\mathrm{SiO}_{2}$, $\mathrm{Fe}_{0.942} \mathrm{O}$ and $\mathrm{Fe}_{2} \mathrm{O}_{3}$. Contrary to earlier observations that the Akpafu Todzi iron consists of predominantly of hematite $\left(\mathrm{Fe}_{2} \mathrm{O}_{3}\right)$ and quartz $\left(\mathrm{SiO}_{2}\right)$, peaks of wustite $\left(\mathrm{Fe}_{0.942} \mathrm{O}\right)$ are seen in the diffractogram of the ore shown in Fig. 13, suggesting that iron exists as the mixed ferrous oxides wustite and hematite. Production of metallic iron from the ore therefore requires simultaneous reduction of both hematite and wustite according to Equations (1) and (2):

$$
\begin{aligned}
& \mathrm{Fe}_{2} \mathrm{O}_{3}+3 \mathrm{C}=2 \mathrm{Fe}+3 \mathrm{CO} \\
& \mathrm{Fe}_{0.942} \mathrm{O}+\mathrm{C}=0.942 \mathrm{Fe}+\mathrm{CO}
\end{aligned}
$$

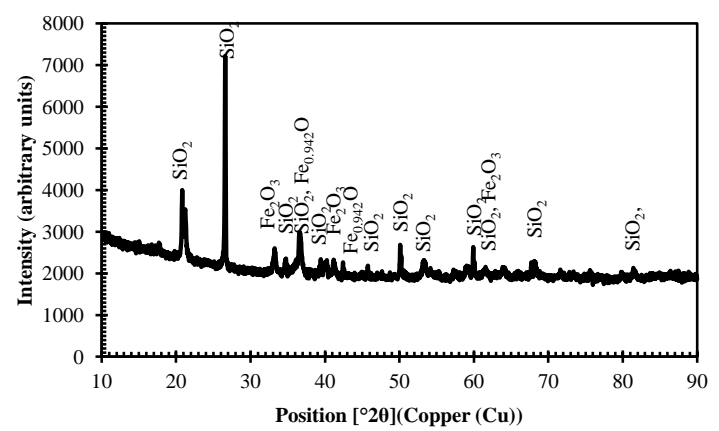

Fig 13. XRD of Akpafu-Todzi Iron Ore

\subsection{The Nature of the Akpafu-Todzi Slag}

The SEM/EDS analyses of the Akpafu-Todzi slag before reduction are illustrated in Figs 14 and 15 for two regions 1 and 2. Region 1 shows an iron content of $50.93 \mathrm{wt} \%$, with Region 2 not very different at 51.73 wt $\%$. These values are higher than those observed for the ore and are just below the minimum 55 wt $\%$ Fe required for economic extraction of iron ores.

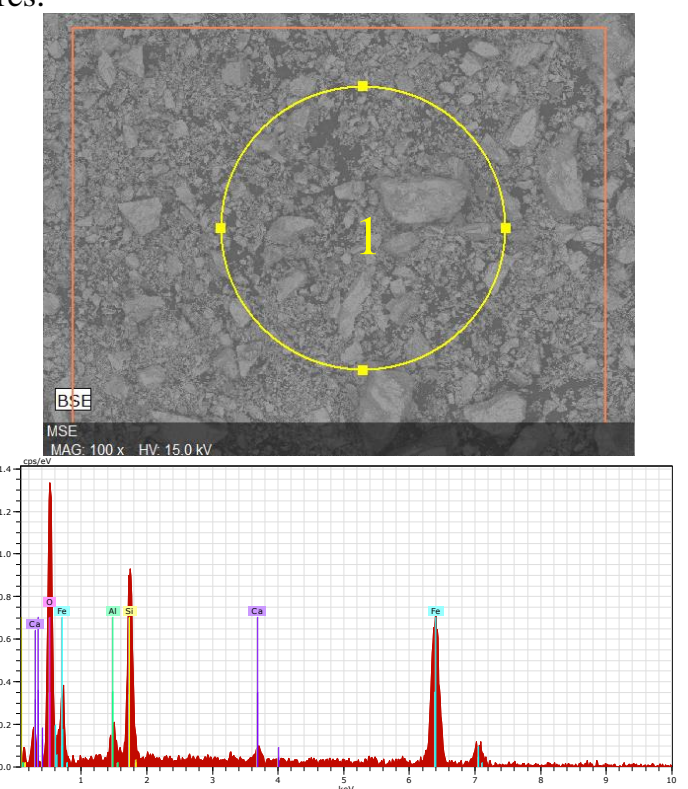

\begin{tabular}{|l|c|c|}
\hline \multicolumn{1}{|c|}{$\begin{array}{c}\text { Element (K- } \\
\text { series) }\end{array}$} & Weight \% & Atomic \% \\
\hline $\mathrm{Fe}$ & 50.93 & 25.90 \\
\hline $\mathrm{O}$ & 32.43 & 57.56 \\
\hline $\mathrm{Si}$ & 13.19 & 13.33 \\
\hline $\mathrm{Al}$ & 2.22 & 2.33 \\
\hline $\mathrm{Ca}$ & 1.24 & 0.88 \\
\hline $\mathrm{SUM}$ & 100 & 100 \\
\hline
\end{tabular}

Fig. 14 SEM/EDS Analysis of Akpafu-Todzi Slag (Region 1)

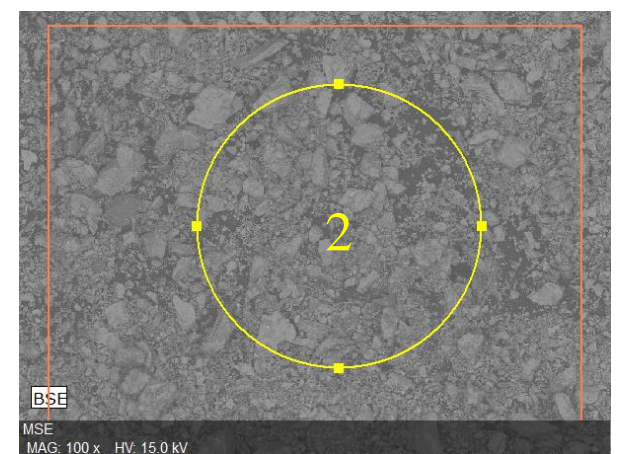




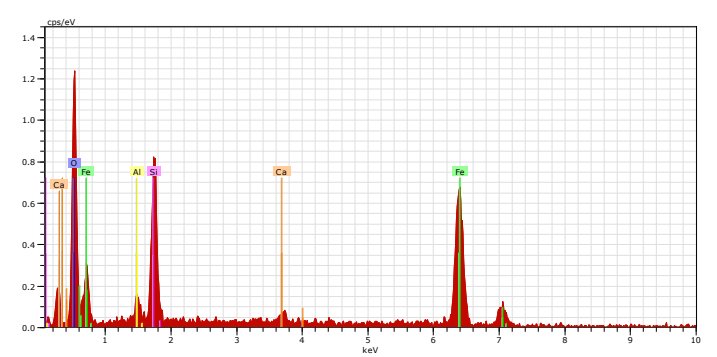

\begin{tabular}{|l|c|c|}
\hline \multicolumn{1}{|c|}{$\begin{array}{c}\text { Element (K- } \\
\text { series) }\end{array}$} & Weight \% & Atomic \% \\
\hline $\mathrm{Fe}$ & 51.73 & 26.63 \\
\hline $\mathrm{O}$ & 31.37 & 56.37 \\
\hline $\mathrm{Si}$ & 13.82 & 14.14 \\
\hline $\mathrm{Al}$ & 1.88 & 2.00 \\
\hline $\mathrm{Ca}$ & 1.20 & 0.86 \\
\hline $\mathrm{SUM}$ & 100 & 100 \\
\hline
\end{tabular}

Fig 15. SEM/EDS Analysis of Akpafu-Todzi Slag (Region 2)

The slag was also characterised by XRD. The diffraction patterns are shown in Fig 16. The diffraction patterns correspond predominantly to those of fayalite $\left(\mathrm{Fe}_{2} \mathrm{SiO}_{4}\right)$ and some $\mathrm{SiO}_{2}$.

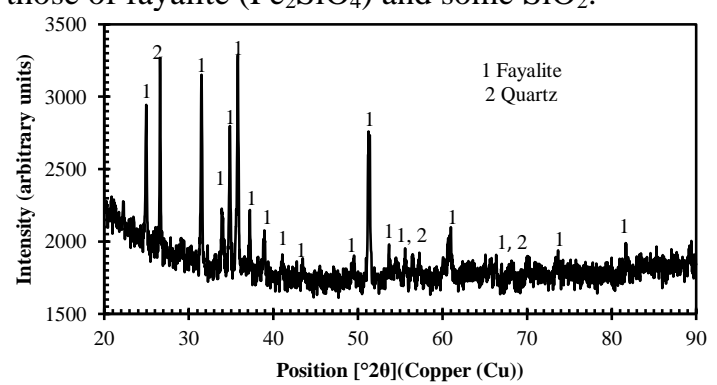

Fig. 16 XRD of Akpafu-Todzi Artisanal Slag

\subsection{Reduction of Akpafu-Todzi Iron Ore and Slag by WES}

Fig 17 shows the nature of metal produced from the reduction of the Akpafu-Todzi slag by carbonaceous materials generated from WES.
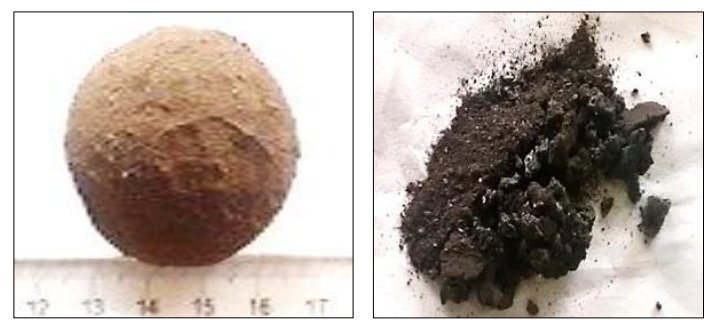

Fig. 17 Green Ore Pellet before and after Firing Slag-WES Composite Pellet

The reduced metals were separated from the unreduced portion of the slag using a hand-held magnetic. Part of the separated metals is shown in Fig. 18.

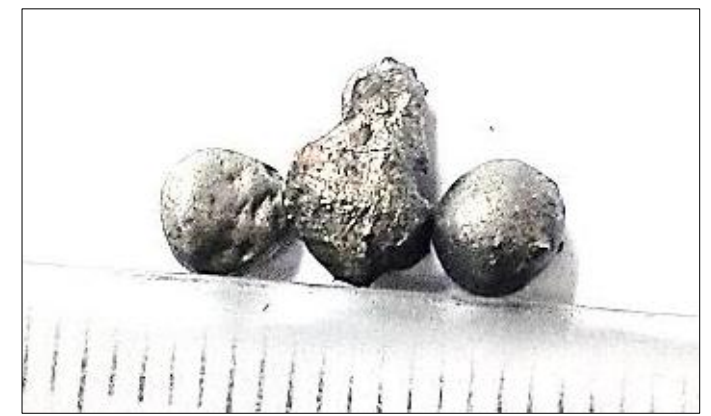

Fig. 18 Metallic Iron Nuggets formed from Slag Sample after Firing

The XRD diffractograms in Fig. 16 showed the slag as consisting predominantly of fayalite $\left(\mathrm{Fe}_{2} \mathrm{SiO}_{4}\right)$ and quartz $\left(\mathrm{SiO}_{2}\right)$. The possible reactions in the microwave oven are:

$$
\mathrm{Fe}_{2} \mathrm{SiO}_{4}+2 \mathrm{CO}=2 \mathrm{Fe}+\mathrm{SiO}_{2}+2 \mathrm{CO}_{2}
$$

The Gibbs free energy change for reaction (3) is given by the expression in eqn. (4), with an equilibrium temperature of approximately $910{ }^{\circ} \mathrm{C}$ : $\Delta \mathrm{G}=12477-10.55 \mathrm{~T}$

Thermodynamic calculation results of fayalite reduction by $\mathrm{CO}$ indicates that addition of an alkaline oxide like $\mathrm{CaO}$ can improve the fayalite reduction by chemically combining with $\mathrm{SiO}_{2}$ to form wollastonite $\left(\mathrm{CaO} \cdot \mathrm{SiO}_{2}\right)$ as shown in eqn. (5) (Xian-Lin et al., 2015; Cheng et al., 2013)

$$
\begin{gathered}
\mathrm{Fe}_{2} \mathrm{SiO}_{4}+\mathrm{CaO}+2 \mathrm{CO}=2 \mathrm{Fe}+\mathrm{CaO} \cdot \mathrm{SiO}_{2}+2 \mathrm{CO}_{2} \\
\Delta \mathrm{G}=-79956+13.06 \mathrm{~T}
\end{gathered}
$$

Increasing the content of $\mathrm{CaO}$ will enhance the formation of dicalcium silicate $\left(2 \mathrm{CaO} \cdot \mathrm{SiO}_{2}\right)$ by solid-phase reaction (Xian-Lin et al., 2015; Cheng et al., 2013; Heo et al., 2013). This contributes to the separation of slag and iron by natural pulverisation of dicalcium silicate during cooling (Xian-Lin et al., 2015; Cheng et al., 2013; Heo et al., 2013).

The reduction of silica by carbon proceeds according to the steps below. In the slag phase $\mathrm{SiO}_{2}$ can be carbothermally reduced to produce silicon metalloid or the refractory material silicon carbide (SiC), according to eqn. 7-8 (Safarian et al., 2008) and eqn. 9-10 (Turkdogan, 1980), respectively.

$$
\begin{gathered}
\left(\mathrm{SiO}_{2}\right)_{(\mathrm{l})}+2 \mathrm{C}=[\mathrm{Si}]_{(\mathrm{l})}+2 \mathrm{CO}_{(\mathrm{g})} \\
\Delta \mathrm{G}^{\mathrm{o}}=677662-347 \mathrm{~T}(\mathrm{~J}) \\
\left(\mathrm{SiO}_{2}\right)+3 \mathrm{C}=\mathrm{SiC}+2 \mathrm{CO}_{(\mathrm{g})} \\
\Delta \mathrm{G}^{\mathrm{o}}=604679-339 \mathrm{~T}(\mathrm{~J})
\end{gathered}
$$

Silica can be reduced by $\mathrm{SiC}$ in accordance with the reaction in eqn. (11) (Olsen et al., 2007).

$$
\begin{aligned}
& \left(\mathrm{SiO}_{2}\right)_{(\mathrm{l})}+2 \mathrm{SiC}=3[\mathrm{Si}]_{(\mathrm{l})}+2 \mathrm{CO}_{(\mathrm{g})} \\
& \Delta \mathrm{G}^{\mathrm{o}}=823627-362 \mathrm{~T}(\mathrm{~J})
\end{aligned}
$$


The equilibrium temperatures for the reaction equations (7), (9) and (11) are 1680, 1510 and 2002 ${ }^{\circ} \mathrm{C}$, respectively. These are extremely high temperatures and processes relying on such reactions would typically consume large amounts of energy.

The maximum temperature recorded in the microwave was about $1197{ }^{\circ} \mathrm{C}$, far below the melting point of metallic iron and excluding the reduction of $\mathrm{SiO}_{2}$ to $\mathrm{Si}$. The metal formed was spherical, suggesting that it solidified from the liquid state. The metal formed is therefore highly carburised or contained some other alloying elements. However, the metal produced from the ore is irregularly shaped as shown in Fig. 19. It suggests solid state reduction.

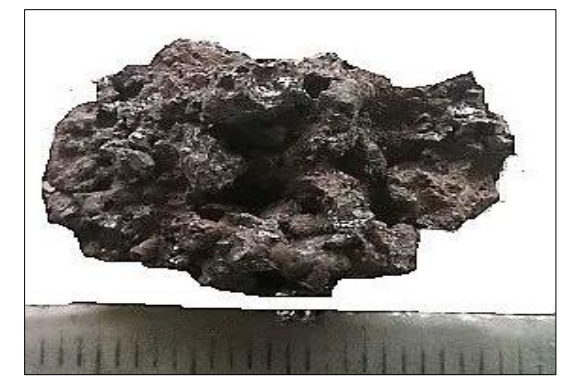

Fig. 19 Reduced Iron formed from Ore after Firing

\subsection{Extent of Reduction of Akpafu-Todzi Iron Ore and Slag by WES}

The extents of reduction of the ore and slag by WES were measured at different times. The results are shown in Fig. 20.

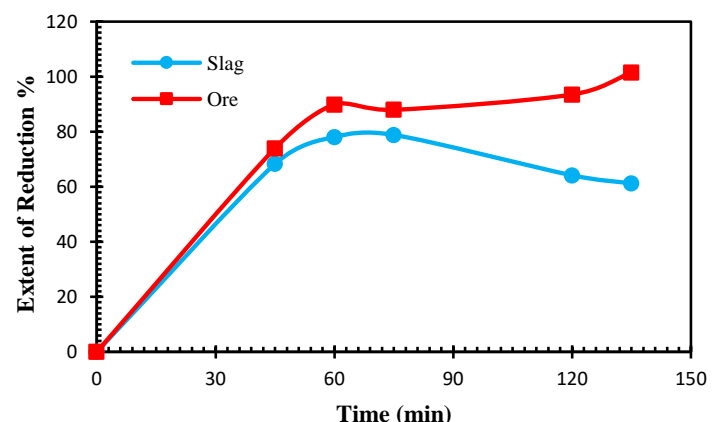

Fig. 20 Graph of Extent of Reduction versus Firing Time

Whereas the ore attained complete reduction, the maximum extent of reduction for the slag is 78.84 $\%$. This disparity in extent of reduction can be attributed to the relative difficulty in reduction of fayalite (the major composition of the slag) as opposed to the reduction of hematite and wustite (from the ore). Accordingly, it is much easier to reduce the ore than the slag, although the content of $\mathrm{Fe}$ in the latter is higher. The $78.84 \%$ extent of reduction of fayalite is similar to results obtained by
Cheng et al. (2013) who attained a metallisation of $77 \%$ and $74 \%$ at $1250{ }^{\circ} \mathrm{C}$ and $1200^{\circ} \mathrm{C}$, respectively. Consequently, even without the usual $\mathrm{CaO}$ and/or $\mathrm{Al}_{2} \mathrm{O}_{3}$ additions, charred WES can perform effectively as reductant for the Akpafu-Todzi ore and the artisanal slag.

\section{Conclusions}

The reduction of the Akpafu-Todzi iron ore and slag has been investigated using carbonaceous material prepared from waste electrical sockets. Major findings of the investigation are:

i. Waste electrical sockets (WES) are a potential source of carbonaceous materials for iron oxide reduction:

ii. The Akpafu-Todzi ore consists of the mixed ferrous ores hematite $\left(\mathrm{Fe}_{2} \mathrm{O}_{3}\right)$ and wustite $\left(\mathrm{Fe}_{0.942} \mathrm{O}\right)$ along with quartz $\left(\mathrm{SiO}_{2}\right)$ :

iii. The Akpafu-Todzi slag is predominantly a fayalite $\left(\mathrm{Fe}_{2} \mathrm{SiO}_{4}\right)$ with significant amounts of quartz.

iv. The Akpafu-Todzi iron ore and slag can be successfully reduced using carbonaceous materials generated from WES.

\section{Acknowledgements}

Part of the analyses for the investigation was conducted at the School of Materials Science and Engineering and the Analytical Centre, School of Chemical Science and Engineering, UNSW, Sydney, Australia. The authors are grateful to the various authorising bodies for the assistance received.

\section{References}

Cheng, X., Zhao, K., Qi, Y., Shi, X. and Zheng, C. (2013), "Direct Reduction Experiment on IronBearing Waste Slag", Journal of Iron and Steel Research International, Vol. 20, No. 3, pp. 2429.

Dankwah, J. R., Koshy, P., Saha-Chaudhury, N. M., O'Kane, P., Skidmore, C., Knights, D. and Sahajwalla, V. (2011), "Reduction of FeO in EAF Steelmaking Slag by Blends of Metallurgical Coke and Waste Plastics", ISIJ International, Vol. 51, No. 3, pp. 498-507.

Dankwah, J. R., Koshy, P., O'Kane, P. and Sahajwalla, V. (2012), "Reduction of $\mathrm{FeO}$ in EAF Steelmaking Slag by Blends of Metallurgical Coke and End-of-Life Tyres", Steel Research International, Vol. 83, No.8, pp. 766-774.

Dankwah, J.R., Koshy P. and Sahajwalla, V.H. (2013), "Reduction of FeO in EAF Steelmaking Slag by Blends of Metallurgical Coke and Endof-Life Polyethylene Terephthalate", Iron- 
making and Steelmaking, Vol. 41, No. 6, pp. 401409.

Dankwah, J.R., and Koshy, P. (2014), "Reduction of $\mathrm{FeO}$ in EAF Steelmaking Slag by Blends of Metallurgical Coke and Waste Polypropylene". High Temperature Materials and Processes, Vol. 33, No. 2, pp. 107-114.

Dankwah, J. R. and Baawuah, E. (2015), "Recycling Waste Bakelite as a Carbon Resource in Ironmaking", International Journal of Scientific and Technology Research (IJSTR), Vol. 4, Issue 2, pp. 257-261.

Dankwah, J. R., Fosu, A.Y., Fosu, N. and Koshy, P., (2015a), "Carbothermal Upgrading of the Awaso Bauxite Ore using Waste Pure Water Sachets as Reductant", Ghana Mining Journal, Vol. 15, No. 1, pp. 64-72.

Dankwah, J. R., Amoah, T., Dankwah, J. and Fosu, A. Y., (2015b), "Recycling Mixed Plastics Waste as Reductant in Ironmaking", Ghana Mining Journal, Vol. 15, No. 2, pp. 73-80.

Dankwah, J. R., Abotar, E., Gordon, J. J. K, and Koshy, P. (2016), "Recycling Waste Electrical Socket as a Carbon Resource in Ironmaking", Ghana Mining Journal, Vol. 16, No. 1, pp. 76 82.

Dankwah, J. R., Agbenuvor, B. S. and Koshy, P. (2016b), "Production of Iron Nuggets from the Akpafu-Todzi Iron Ore using Waste Plastics and Waste Biomass as Reductants" Ghana Journal of Technology, Vol. 1, No. 1, pp. 53-60.

Dhunna, R., Khanna, R., Mansuri, I. and Sahajwalla, V., (2014), "Recycling Waste Bakelite as an Alternative Carbon Resource for Ironmaking", ISIJ International, Vol. 54, No. 3, pp. 613-619.

Heo, J. H., Chung, Y. and Park, J. H. (2016), "Recovery of Iron and Removal of Hazardous Elements from Waste Copper Slag via a Novel Aluminothermic Smelting Reduction (ASR) Process", Journal of Cleaner Production, Vol. 137, pp. 777-787.

Heo, J. H., Kim, B. and Park, J. H. (2013), "Effect of $\mathrm{CaO}$ Addition on Iron Recovery from Copper Smelting Slags by Solid Carbon", Metall. Mater. Trans. B, Vol. 44, No. 6, pp. 1352-1363.

Kongkarat, S., Khanna, R., Koshy, P., O’Kane, P., and Sahajwalla, V. (2011), "Use of Waste Bakelite as a Raw Material Resource for Recarburization in Steelmaking Processes" Steel Research International, Vol. 82(10), pp. 12281239.

Mansuri, I. A., Khanna, R., Rajarao, R. and Sahajwalla, V., (2013), "Recycling Waste CDs as Carbon Resource: Dissolution of Carbon into Molten Iron at $1550^{\circ} \mathrm{C}$, ISIJ International, Vol. 53, No. 12, pp. 2259-2265.

Matsuda, T., Takekawa, M., Hasegawa, M., Ikemura, Y., Wakimoto, K., Ariyama, T., and Iwase, M. (2006), "Utilization of Waste Wood for Production of Iron, Carbon Monoxide and
Hydrogen without Generating Carbon Dioxide", Steel Res. Int., Vol. 77, pp. 774-784.

Matsuda, T., Hasegawa, M., Ikemura, A., Wakimoto, K., and Iwase, M. (2008), "Utilization of Waste Plastic for Production of Metallic Iron, Hydrogen and Carbon Monoxide without Generating Carbon Dioxide", ISIJ Int., Vol. 48, No. 9, pp. 1186-1196.

Murakami, T., Akiyama, T. and Kasai, E., (2009), "Reduction Behaviour of Hematite Composite containing Polyethylene and Graphite with Different Structures with Increasing Temperature", ISIJ Int., 49(6), pp. 809-814.

Murakami, T. and Kasai, E., (2011), "Reduction Mechanism of Iron Oxide-carbon Composite with Polyethylene at Lower Temperature", ISIJ Int., 51(1), pp. 9-13.

Nath, D. C. D., Mansuri, I. A., Zaharia, M., Saha Chaudhury, N. and Sahajwalla, V., (2012), "Recycling End-of-Life Melamine at $1600{ }^{\circ} \mathrm{C}$ for Carbon Dissolution into Liquid Iron", ISIJ International, Vol. 52, No. 5, pp. 922-927.

Nishioka, K., Taniguchi, T., Ueki, Y., Ohno, K., Maeda, T., and Shimizu, M. (2007), "Gasification and Reduction Behaviour of Plastic and Iron Ore Mixtures by Microwave Heating”, ISIJ Int., Vol. 47, No. 4, pp. 602-607.

Rajarao, R., Mansuri, I. A., Dhunna, R., Khanna, R. and Sahajwalla, V., (2014a), "Characterisation of Gas Evolution and Char Structural Change during Pyrolysis of Waste CDs", Journal of Analytical and Applied Pyrolysis, Vol. 105, pp. 14-22.

Rajarao, R., Mansuri, I., Dhunna, R. and Sahajwalla, V., (2014b), "Study of Structural Evolution of Chars during Rapid Pyrolysis of Waste CDs at Different Temperatures", Fuel, Vol. 134, pp. 1725.

Sarfo, P., Wyss, G., Ma, G., Das, A. and Young, C. (2017), "Carbothermal Reduction of Copper Smelter Slag for Recycling into Pig Iron and Glass", Minerals Engineering, Vol. 107, pp. 819.

Ueki, Y., Ohno, K., Maeda, T., Nishioka, K. and Shimizu, M. (2008), "Reaction Behaviour during Heating Waste Plastic Materials and Iron Oxide Composites", ISIJ Int., Vol. 48, pp. 1670-1675.

Xian-Lin, Z., De-Qing, Z., Jian, P. and Teng-Jiao, W. (2015), "Utilization of Waste Copper Slag to Produce Directly Reduced Iron for Weathering Resistant Steel", ISIJ International, Vol. 55, No. 7, pp. 1347-1352. 


\section{Authors}

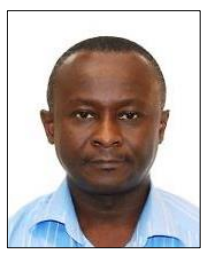

James R. Dankwah is an Associate Professor at the University of Mines and Technology, UMaT-Tarkwa. He obtained his $\mathrm{PhD}$ from the School of Materials Science and Engineering, UNSW-Australia, MSc (Process Metallurgy) from the Norwegian University of Science and Technology and BSc (Metallurgical Engineering) from the Kwame Nkrumah University of Science and Technology, Kumasi, Ghana. He is a Fellow of the West African Institute of Mining, Metallurgy and Petroleum (WAIMM). His current research areas include iron and steelmaking, high-temperature metallurgical processes, utilisation of waste polymers in metal extraction processes and recycling agricultural waste into building blocks materials for affordable housing for the rural folks.

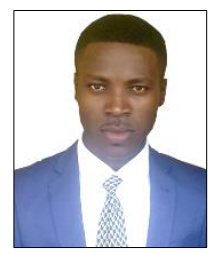

Eric O. Baah is a researcher at the Africa Centre for Sustainable Materials Research and Technology (ACeSMaRT), Tarkwa. He completed his BSc degree in Minerals Engineering at the University of Mines and Technology, Tarkwa, Ghana). His current research areas include the recycling of postconsumer plastics in the reduction of metal

oxides.

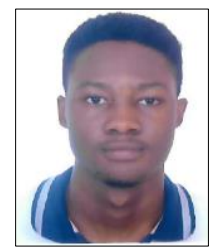

James B. Dankwah is a researcher at the Africa Centre for Sustainable Materials Research and Technology (ACeSMaRT), Tarkwa. He completed his BSc degree in Minerals Engineering at the University of Mines and Technology, Tarkwa, Ghana His current research is the production of ferrosilicon alloys from the nonmagnetic portion of the Pudo iron ore using end-of-life plastics as reducing agents.

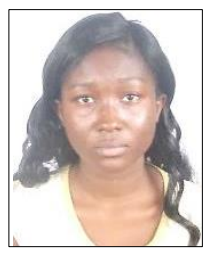

Jessica Dankwah is a researcher at the Africa Centre for Sustainable Materials Research and Technology (ACeSMaRT), Tarkwa. She completed her BSc degree in Chemical Engineering at the Kwame Nkrumah University of Science and Technology, Kumasi, Ghana. She is currently pursuing her MPhil Degree at the University of Mines and Technology, Tarkwa. Her current research is the recycling of post-consumer plastics in the reduction of metal oxides and the production of liquid fuels (diesel, kerosene and aviation fuel).

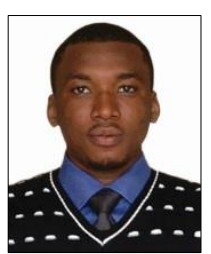

Bernard S. Agbenuvor is currently pursuing his Master of Research Degree at the University of Queensland, Australia. He obtained his BSc degree in Minerals Engineering from the University of Mines and Technology, Tarkwa, Ghana. His current research was the utilisation of blends of waste plastics with biomass as reductants in ironmaking, with emphasis on the Akpafu-Todzi iron ore from the Volta Region of Ghana.

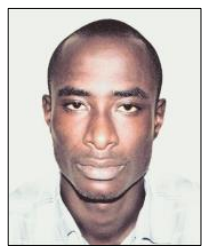

Bismark Amankwaa-Kyeremeh is currently pursuing his $\mathrm{PhD}$ Degree at the IANWARK research centre, University of South Australia, Australia. He obtained his BSc degree in Minerals Engineering at the University of Mines and Technology, Tarkwa, Ghana. His current research was on the production of ferrosilicon alloys from the nonmagnetic portion of the Pudo iron ore using end-of-life plastics as reducing agents.

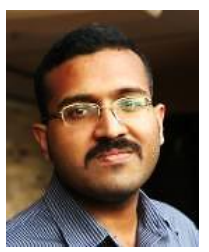

Pramod Koshy is a Senior Research Fellow at the School of Materials Science and Engineering, UNSW, Australia. He completed his Ph.D. from the School of Materials Science and Engineering, UNSW, Australia. His main areas of research include photocatalytic materials, high-temperature waste materials. metal/ceramic interfaces, and utilization of 